Article

\title{
Ternary N, S, and P-Doped Hollow Carbon Spheres Derived from Polyphosphazene as Pd Supports for Ethanol Oxidation Reaction
}

\author{
Ke Yu ${ }^{1}$, Yan Lin ${ }^{1}$, Jinchen Fan ${ }^{1,2,3, *}$, Qiaoxia Li ${ }^{1,3}$, Penghui Shi ${ }^{1,3}$, Qunjie $\mathrm{Xu}^{1,3, *}$ and \\ Yulin Min ${ }^{1,3}$ \\ 1 Shanghai Key Laboratory of Materials Protection and Advanced Materials in Electric Power, College of \\ Environmental and Chemical Engineering, Shanghai University of Electric Power, Shanghai 200090, China; \\ pjyuke1994@gmail.com (K.Y.); yanlinshiep2019@gmail.com (Y.L.); liqiaoxia2003@126.com (Q.L.); \\ shipenghui@shiep.edu.cn (P.S.); minyulin@shiep.edu.cn (Y.M.) \\ 2 Department of Chemical Engineering and Biointerfaces Institute, University of Michigan, Ann Arbor, \\ MI 48109, USA \\ 3 Shanghai Institute of Pollution Control and Ecological Security, Shanghai 200092, China \\ * Correspondence: jinchen.fan@shiep.edu.cn (J.F.); xuqunjie@shiep.edu.cn (Q.X.)
}

Received: 6 January 2019; Accepted: 22 January 2019; Published: 26 January 2019

\begin{abstract}
Ethanol oxidation reaction (EOR) is an important electrode reaction in ethanol fuel cells. However, there are many problems with commercial ethanol oxidation electrocatalysts today, such as poor durability, poor anti-CO poisoning ability, and low selectivity for $\mathrm{C}-\mathrm{C}$ bond cleavage. Therefore, it is very meaningful to develop a high-performance EOR catalyst. Herein, we designed ternary $\mathrm{N}, \mathrm{S}$, and P-doped hollow carbon spheres $(\mathrm{C}-\mathrm{N}, \mathrm{P}, \mathrm{S})$ from polyphosphazene (PCCP) as Pd supports for EOR. Using $\mathrm{SiO}_{2}$ spheres as the templates, the PCCP was first coated on the surfaces of $\mathrm{SiO}_{2}$ spheres by in situ polymerization. Through high-temperature pyrolysis and hydrofluoric acid-etching, the hollow PCCP has a large surface area and porous structure. After loading Pd nanoparticles (NPs), the Pd/C-N, P, S catalysts with Pd NPs decorated on the surfaces of C-N, P, S can achieve a high mass peak current density of $1686 \mathrm{~mA} \mathrm{mg}_{\mathrm{Pd}^{-1}}{ }^{-1}$, which was 2.8 times greater than that of $\mathrm{Pd} / \mathrm{C}$. Meanwhile, the Pd/C-N, P, S catalyst also shows a better stability than that of Pd/C after a durability test of 3600s.
\end{abstract}

Keywords: ethanol oxidation reaction; palladium; hollow carbon sphere; alkaline medium

\section{Introduction}

Recently, direct ethanol fuel cells (DEFCs) have become the ideal solution to the energy crisis and environmental issues and, therefore, have attracted enormous interest. Specifically, DEFCs have many advantages such as high efficiency, high energy density, low pollution, and excellent electrochemical stability. Besides, the biomass fuel ethanol is widely used because of its many advantages, such as easy to store, non-toxic, simple to synthesize [1-4]. The ethanol oxidation reaction (EOR) is a crucial reaction in DEFCs, which is the most important part of determining the performance of the entire fuel cell. Platinum $(\mathrm{Pt})$ is the most widely used precious metal for EOR in acidic media because of its attractive characteristics of high electrochemical activity and low over potential. Unfortunately, high cost and poor anti-poisoning have inhibited Pt-based catalysts application in DEFCs [5,6]. Because of this, many researchers have turned their attention to another metal. Some studies have found that Palladium $(\mathrm{Pd})$ is a more suitable alternative than Pt in DEFC. Although the Pd-based catalyst activity in the acidic medium is not as good as that of the Pt-based catalyst, the Pd-based catalyst performs better than the Pt-based catalyst in the alkaline medium. Regarding price, Pd is cheaper than $\mathrm{Pt}$, which significantly reduces the cost of experimentation and research [7-11]. 
As we all know, the activity and stability of an electrocatalyst depends significantly on the composition and structure of the supported catalysts and metallic nanoparticles. Therefore, the construction of a new type of Pd-incorporated supported catalyst can play an important role in DEFCs. Carbon-based materials often serve as catalyst supports because of their good electrical conductivity and stability. So far, graphene, carbon microspheres, carbon nanotubes and carbon black have widely been employed as supporting materials of Pd [12-15]. As is well-known, catalyst supports need not only a large specific surface area but also good electrical conductivity, so that the noble metal particles have a high dispersion state while exposing more active sites. Many studies have shown that materials with hollow structures and mesopores can serve as good supports for electrocatalysts. Material such as mesoporous hollow carbon hemispheres [16], spherical carbon capsules [17], hollow graphitized carbon nanocage [18] were used as supports of noble metals electrocatalysts due to their large specific surface area and high stability. Moreover, core-shell structures are widely used in the preparation of catalysts, such as Pd@porous $\mathrm{SiO}_{2}$ yolk-shell nanostructure [19], $\mathrm{PdO} / \mathrm{ZnO} @ \mathrm{mSiO}_{2}$ [20], $\mathrm{Cu} @ \mathrm{Cu}_{2} \mathrm{O}$ core-shell nanocatalyst [21].

On the other hand, heteroatom-doped carbon materials are considered to be better catalyst supports than pristine carbon-based supports. Studies have indicated that heteroatom doping can effectively improve catalyst activity and make more active sites exposed [22-24]. In particular, when two or more elements, such as N, S, etc. are doped in the structure of carbon, the catalyst activity can improve obviously. That is because $\mathrm{N}$ and $\mathrm{S}$ as dopants can create synergistic effects that make them easier to modulate for some conjugated bonds and electron distribution, and then making catalysis more efficient [25]. Furthermore, $\mathrm{P}$ atom doping could also improve the active sites of the carbon materials [26-28].

In summary, $\mathrm{N}, \mathrm{S}$, and $\mathrm{P}$ - ternary hollow carbon sphere materials can be used as good precious metal carriers. In this work, $\mathrm{N}, \mathrm{S}$, and P- ternary hollow carbon sphere materials $(\mathrm{C}-\mathrm{N}, \mathrm{P}, \mathrm{S})$ were fabricated by a one-step procedure with high-temperature pyrolysis of polyphosphazene coated $\mathrm{SiO}_{2}$ spheres template composites, followed by removing $\mathrm{SiO}_{2}$ spheres template via HF solution etching. Finally, Pd nanoparticles were grown on the surfaces of $\mathrm{C}-\mathrm{N}, \mathrm{P}, \mathrm{S}$ via the immersion reduction method. The as-prepared $\mathrm{Pd} / \mathrm{C}-\mathrm{N}, \mathrm{P}, \mathrm{S}$ catalysts exhibited superior electrocatalytic performance toward EOR than that of $\mathrm{Pd} / \mathrm{C}$. We have reason to believe that the $\mathrm{Pd} / \mathrm{C}-\mathrm{N}, \mathrm{P}, \mathrm{S}$ catalyst can be a commercial $\mathrm{Pd} / \mathrm{C}$ alternative in practical applications towards EOR in the future.

\section{Results and Discussion}

The morphologies and microstructures of the precursors and Pd/C-N,P,S catalysts were first investigated by scanning electron microscope (SEM) and transmission electron microscope (TEM) images. As shown in Figure 1a, the SEM image of pure $\mathrm{SiO}_{2}$ microsphere templates exhibits uniform with the diameters ranged from 300 to $500 \mathrm{~nm}$. Through in situ polymerization, the polyphosphazene (PCCP) was coated on the surfaces of $\mathrm{SiO}_{2}$ microspheres. From the Figure $1 \mathrm{~b}$, the obtained PCCP-coated $\mathrm{SiO}_{2}$ microspheres ( $\mathrm{PCCP} @ \mathrm{SiO}_{2}$ ) show the core-shell structures. From the edge, the thickness of the PCCP layer is about $140 \mathrm{~nm}$. Afterward, the $\mathrm{PCCP} @ \mathrm{SiO}_{2}$ was pyrolyzed at $900{ }^{\circ} \mathrm{C}$. From the SEM image (Figure 1c), the pyrolyzed $\mathrm{PCCP} @ \mathrm{SiO}_{2}$ still remained spherical with a certain fusion. After etching by $\mathrm{HF}$ solution, the $\mathrm{SiO}_{2}$ templates were removed and $\mathrm{C}-\mathrm{N}, \mathrm{P}, \mathrm{S}$ were formed. Finally, using $\mathrm{C}-\mathrm{N}, \mathrm{P}, \mathrm{S}$ as the supports, the $\mathrm{Pd} / \mathrm{C}-\mathrm{N}, \mathrm{P}, \mathrm{S}$ was prepared by using in situ reduction. As observed in Figure $1 \mathrm{~d}, \mathrm{Pd} / \mathrm{C}-\mathrm{N}, \mathrm{P}, \mathrm{S}$ shows the distinct uniform hollow struture with Pd NPs decorated on the surface. In the EDS elemental mapping (Figure 1e-i), the C, N, P, S, Pd elements are distributed on the surfaces of Pd/C-N,P,S, demonstrating su18ccessful fabrication of Pd/C-N,P,S catalysts. 

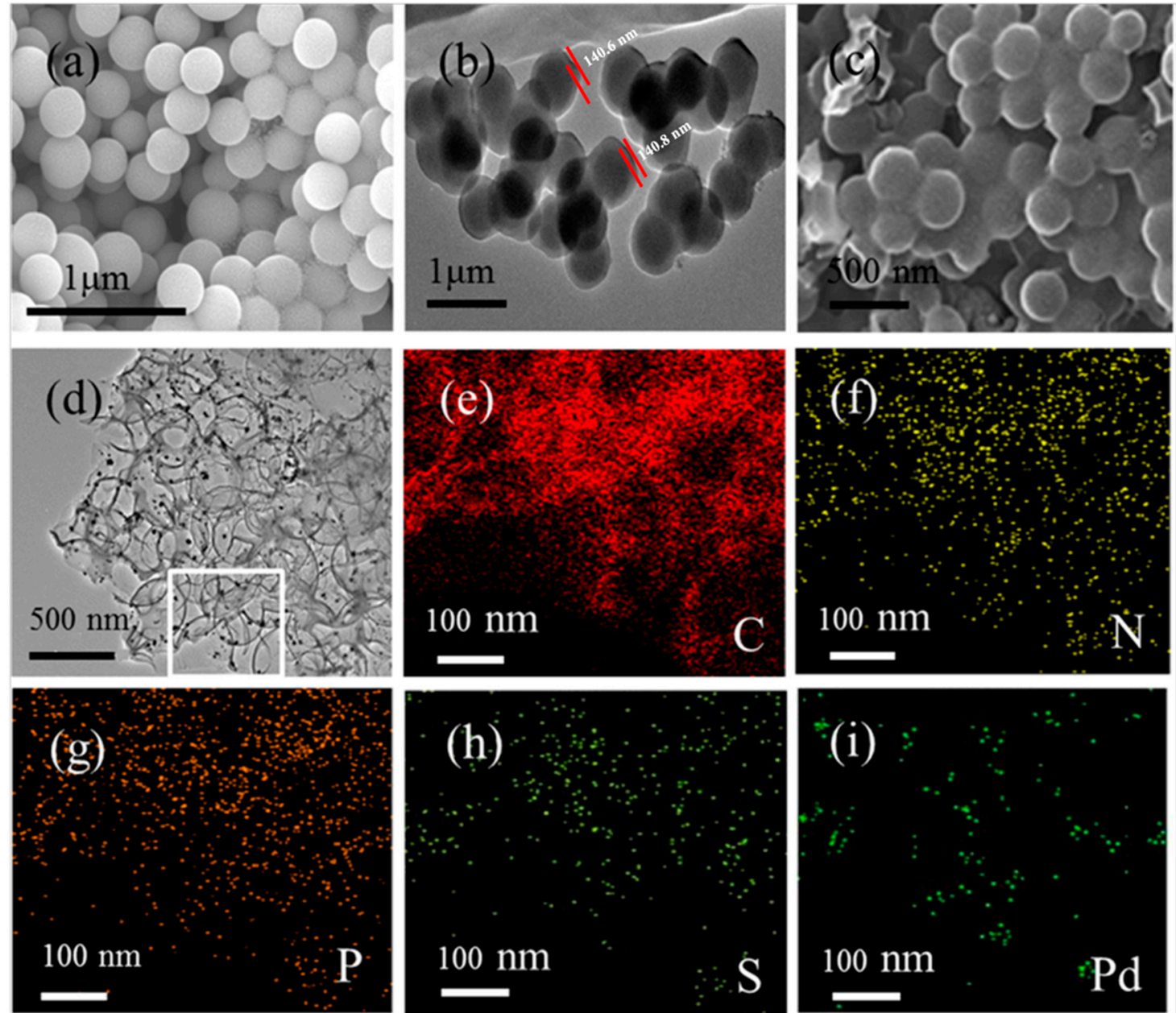

Figure 1. Scanning electron microscope (SEM) images of (a) $\mathrm{SiO}_{2}$, transmission electron microscope

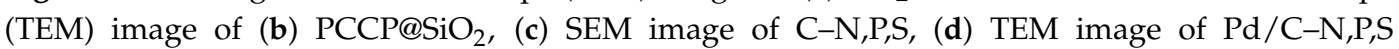
and electrospray ionization (EDS) elemental mapping of (e-i) C, N, P, S, and Pd elements for $\mathrm{Pd} / \mathrm{C}-\mathrm{N}, \mathrm{P}, \mathrm{S}$ catalysts.

Furthermore, from the high-resolution TEM (HRTEM) image of the Pd/C-N,P,S (Figure 2a), the metallic Pd NPs with distinct lattice fringe were close contact with the surface of C-N,P,S which benefits the synergistic effect between the Pd and C-N,P,S. The diameter of Pd NPs is $\sim 5 \mathrm{~nm}$. The lattice fringe spacing of $d=0.22 \mathrm{~nm}$ is attributed to the (111) planes of metallic Pd. Figure 2b shows the X-ray diffraction (XRD) patterns of as-prepared $\mathrm{Pd} / \mathrm{C}$ and $\mathrm{Pd} / \mathrm{C}-\mathrm{N}, \mathrm{P}, \mathrm{S}$. The characteristic peak at $2 \theta=25^{\circ}$ is corresponded to the $\mathrm{C}(002)$ crystal plane. The $\mathrm{Pd} / \mathrm{C}$ and $\mathrm{Pd} / \mathrm{C}-\mathrm{N}, \mathrm{P}, \mathrm{S}$ all show characteristic peaks at $2 \theta$ values of $39.1^{\circ}, 45.1^{\circ}, 66.1^{\circ}$, and $79.7^{\circ}$, which were assigned to (111), (200), (220) and (311) crystal planes of face-centered cubic (fcc) Pd (JCPDS 65-6174), respectively. This agrees with the analysis of the HRTEM image. Figure 3 is the X-ray photoelectron spectroscopy (XPS) spectra of the Pd/C-N, P, $\mathrm{S}$ catalyst. The coexistences of $\mathrm{C}, \mathrm{O}, \mathrm{N}, \mathrm{P}, \mathrm{S}$, and Pd elements are all in the structure of $\mathrm{Pd} / \mathrm{C}-\mathrm{N}, \mathrm{P}, \mathrm{S}$ (Figure 3a).The presence of $\mathrm{O}$ element may come from the surface hydroxyl groups. In Figure 3b, the high-resolution $C 1 \mathrm{~s}$ XPS spectra were deconvoluted into three distinct peaks which are located at $284.6,285.5$, and $286.7 \mathrm{eV}$, respectively. The first peak is the classical peak of the $\mathrm{sp}^{2-}$ hybridized $\mathrm{C}-\mathrm{C}$ bond, while the second peak contributes to the $\mathrm{C}-\mathrm{N}$ or $\mathrm{C}-\mathrm{S}$ backbone. Besides, the third peak is determined as the $\mathrm{C}-\mathrm{O}$ groups $[23,29]$. Furthermore, we also carried out high-resolution XPS analysis of N 1s, P 2p, S 2p and Pd 3d. As shown in Figure 3c, there are two peaks at 398.4 (pyridinic-N) and $402.1 \mathrm{eV}$ (pyridinic-oxide- $\mathrm{N}$ ) in the deconvoluted $\mathrm{N}$ 1s peak [30,31]. The $\mathrm{P} 2 \mathrm{p}$ peak at $133.8 \mathrm{eV}$ can be assigned as the P-N bond (Figure 3d) [26,32]. From the S 2p spectra (Figure 3e), the two peaks at 164.4 
and $168.5 \mathrm{eV}$ are contributed to the $-\mathrm{S}-\mathrm{C}-\mathrm{S}-$ and $-\mathrm{C}-\mathrm{S}(\mathrm{O}) \mathrm{X}-\mathrm{C}-$ groups, which prove that the doped $S$ atoms are tightly bound to the adjacent $C$ atoms [32]. Meanwhile, the high-resolution Pd 3p XPS spectra shown in Figure $3 \mathrm{f}$ were deconvoluted into two groups peaks: the peaks at 335.7 and $341 \mathrm{eV}$ are contributed to the metallic Pd. In addition, the other XPS peaks at 337.0 and $342.5 \mathrm{eV}$ could be ascribed to Pd oxide species [33,34].
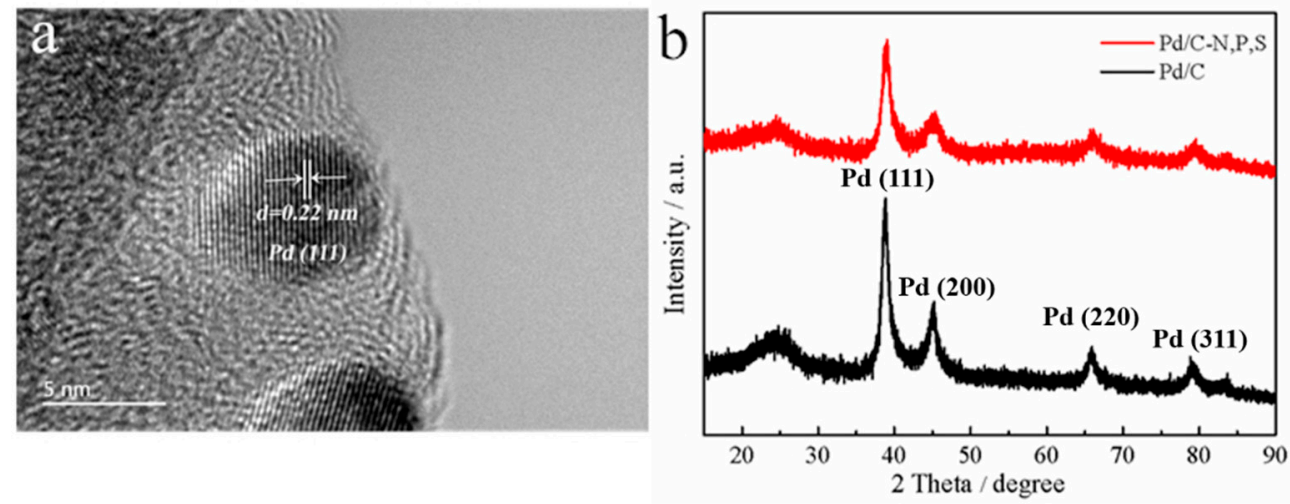

Figure 2. (a) The high-resolution TEM (HRTEM) image of the sample Pd/C-N,P,S, (b) X-ray diffraction (XRD) patterns of C-N,P,S, Pd/C and Pd/C-N,P,S.
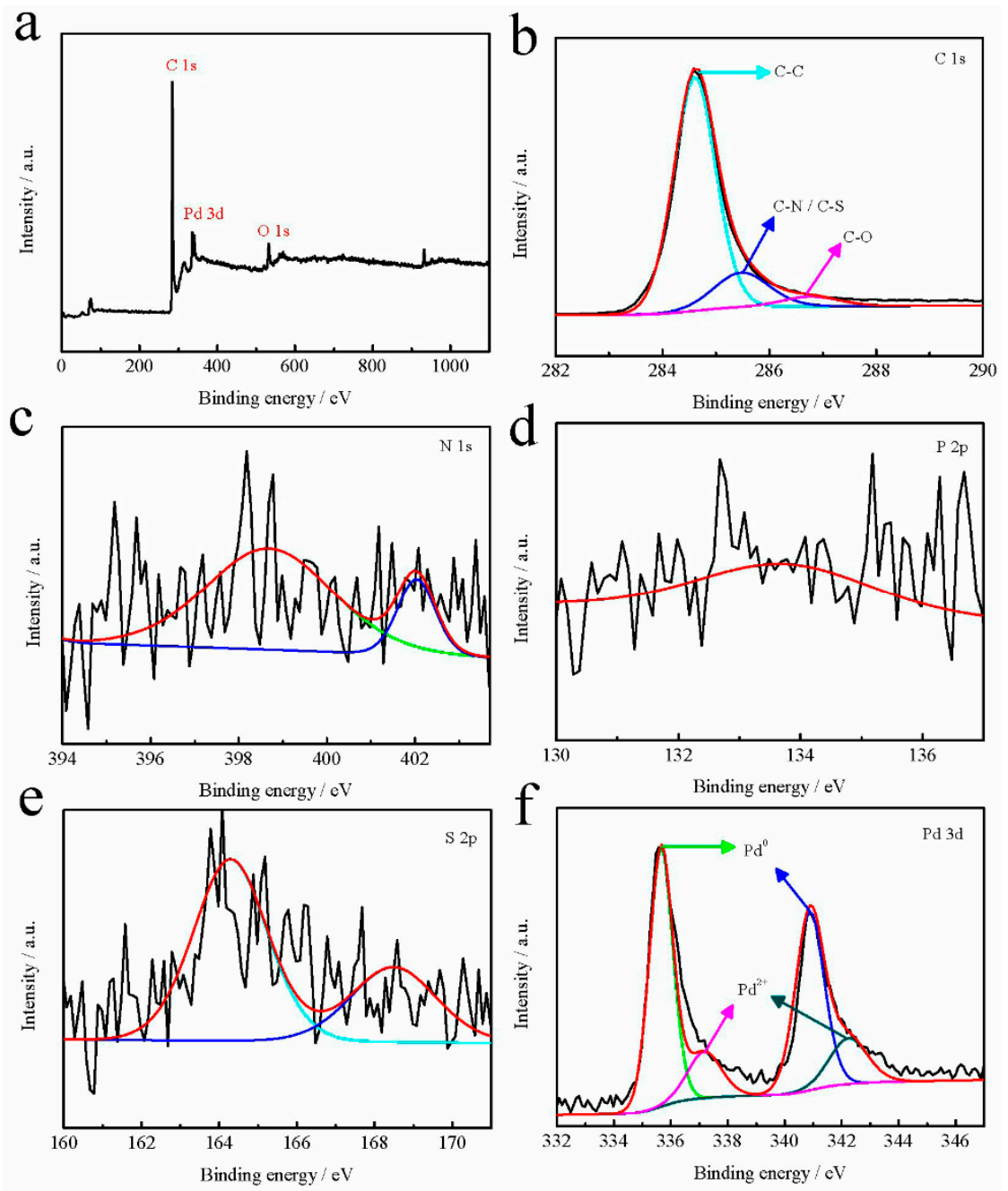

Figure 3. (a) X-ray photoelectron spectroscopy (XPS) surveys of the Pd/C-N,P,S catalyst and core-level spectra for (b) C 1s, (c) N 1s, (d) P 2p, (e) S 2p and (f) Pd 3d. 
Figure $4 a, b$ show the $\mathrm{N}_{2}$ adsorption-desorption isothermals over typical samples of C-N,P,S, and $\mathrm{Pd} / \mathrm{C}-\mathrm{N}, \mathrm{P}, \mathrm{S}$. According to the original International Union of Pure and Applied Chemistry (IUPAC) classification, the $\mathrm{C}-\mathrm{N}, \mathrm{P}, \mathrm{S}$, and $\mathrm{Pd} / \mathrm{C}-\mathrm{N}, \mathrm{P}, \mathrm{S}$ both exhibit type-IV isotherms, and their hysteresis loops are clear $\mathrm{H} 4$ type hysteresis loops. The BET specific surface areas of $\mathrm{C}-\mathrm{N}, \mathrm{P}, \mathrm{S}$, and $\mathrm{Pd} / \mathrm{C}-\mathrm{N}, \mathrm{P}, \mathrm{S}$ are 801 and $212 \mathrm{~m}^{2} \mathrm{~g}^{-1}$,respectively. Furthermore, from the inset $\mathrm{BJH}$ pore size and pore size distributions, the pore sizes of the $\mathrm{C}-\mathrm{N}, \mathrm{P}, \mathrm{S}$, and $\mathrm{Pd} / \mathrm{C}-\mathrm{N}, \mathrm{P}, \mathrm{S}$ are about $\sim 4 \mathrm{~nm}$. The large specific surface area of $\mathrm{C}-\mathrm{N}, \mathrm{P}, \mathrm{S}$ supports with porous structure can facilitate the infiltration of electrolyte and charge transport in EOR, thereby enhancing the electrochemical activity. As can be seen from Figure $4 c$, in the Fourier transform-infrared (FT-IR) spectra of $\mathrm{SiO}_{2}, \mathrm{PCCP@SiO} 2$ and pyrolytic $\mathrm{PCCP@} \mathrm{SiO}_{2}$ composites, the characteristic peaks at 464,795 , and $1092 \mathrm{~cm}^{-1}$ are attributed to the bending and symmetrical stretching vibrations of $\mathrm{Si}-\mathrm{O}-\mathrm{Si}$, respectively. Besides, the peak at $952 \mathrm{~cm}^{-1}$ is attributed to the specific vibration of $\mathrm{Si}-\mathrm{O}$. The peak at $3453 \mathrm{~cm}^{-1}$ is assigned to the vibration of hydroxyl groups on the surfaces of $\mathrm{SiO}_{2}$ microspheres. As templates, the $\mathrm{PCCP} @ \mathrm{SiO}_{2}$ with $\mathrm{PCCP}$ is coated on the surfaces of $\mathrm{SiO}_{2}$ microspheres. Toward PCCP@SiO 2 , the absorption peaks at 1588 and $1490 \mathrm{~cm}^{-1}$ originate from the benzene ring in PCCP. The peaks at 1295 and $1154 \mathrm{~cm}^{-1}$ are ascribed to the sulfone in PCCP. Furthermore, the peaks at 1187 and $887 \mathrm{~cm}^{-1}$ originate from the vibrations of $\mathrm{P}=\mathrm{N}$ and $\mathrm{P}-\mathrm{N}$ in the structure of PCCP. More importantly, the characteristic peak at $949 \mathrm{~cm}^{-1}$ implied the formation of $\mathrm{P}-\mathrm{O}-$ benzene ring. Therefore, the PCCP can be grafted onto the surfaces of $\mathrm{SiO}_{2}$ microspheres via in situ polymerization. As for sample pyrolytic PCCP@SiO $\mathrm{S}_{2}$, the characteristic peaks of PCCP disappeared. The peaks at 470 and $800 \mathrm{~cm}^{-1}$ are corresponded to the symmetrical stretching vibration of Si-O. It demonstrates that the layer of PCCP in the PCCP@ $\mathrm{SiO}_{2}$ has already changed into porous carbon structure. Figure $4 \mathrm{~d}$ shows the Raman spectra for the samples of $\mathrm{C}-\mathrm{N}, \mathrm{P}, \mathrm{S}$ and $\mathrm{Pd} / \mathrm{C}-\mathrm{N}, \mathrm{P}, \mathrm{S}$ composites. The D and G bands of carbon were observed at $\sim 1335$ and $\sim 1595 \mathrm{~cm}^{-1}$ [35]. The value of $\mathrm{I}_{\mathrm{D}} / \mathrm{I}_{\mathrm{G}}$ for the $\mathrm{C}-\mathrm{N}, \mathrm{P}, \mathrm{S}(\approx 1.1)$ was lower than that of the $\mathrm{Pd} / \mathrm{C}-\mathrm{N}, \mathrm{P}, \mathrm{S}(\approx 1.18)$, which could be due to increased defects in $\mathrm{C}$ atom for the $\mathrm{Pd} / \mathrm{C}-\mathrm{N}, \mathrm{P}, \mathrm{S}$ after Pd NPs decoration.
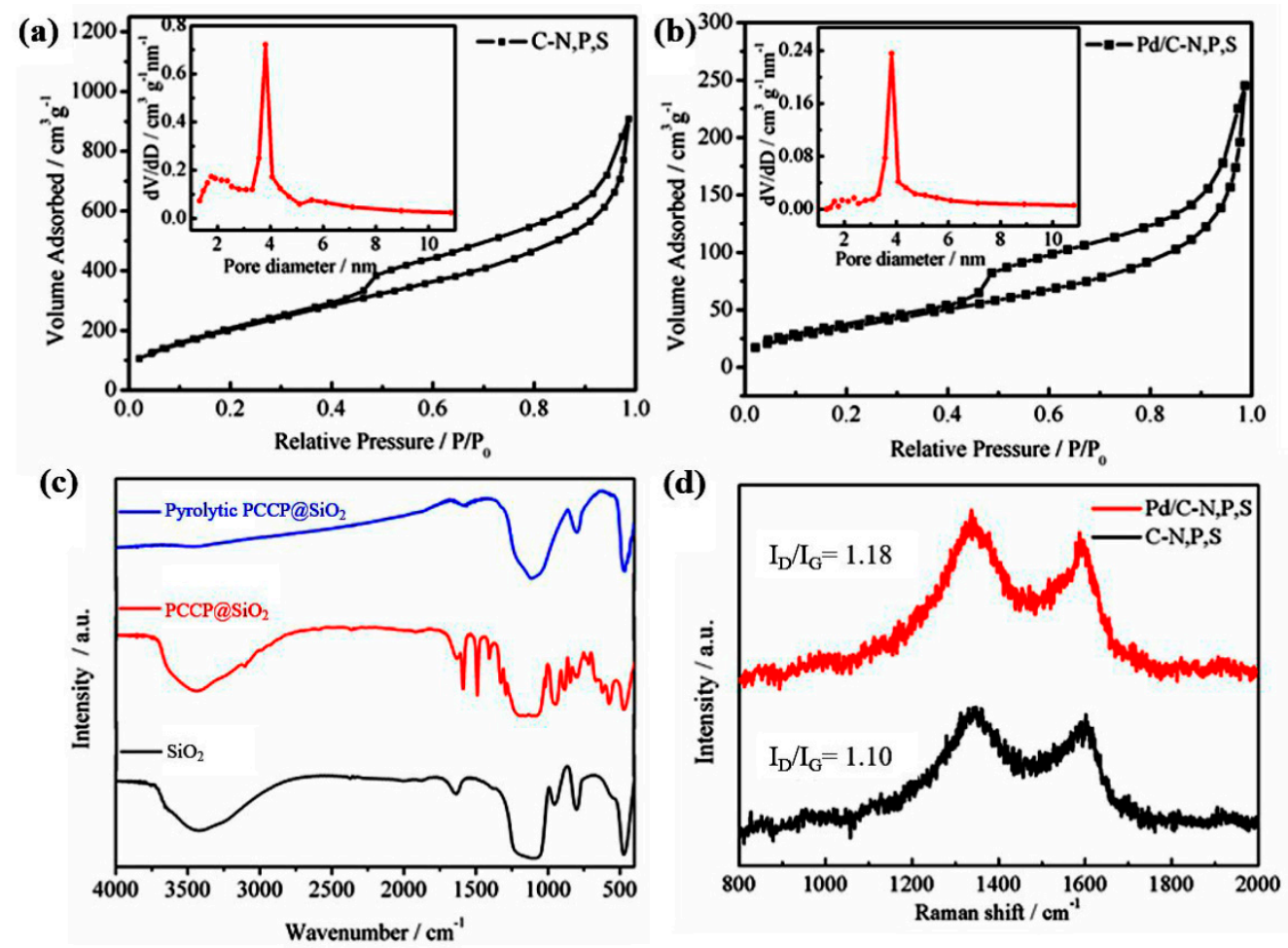

Figure 4. (a) $\mathrm{N}_{2}$ adsorption-desorption isotherm images of $\mathrm{C}-\mathrm{N}, \mathrm{P}, \mathrm{S}$ and (b) $\mathrm{Pd} / \mathrm{C}-\mathrm{N}, \mathrm{P}, \mathrm{S}$ and pore-size distributions, (c) Fourier transform-infrared (FT-IR) spectra for $\mathrm{SiO}_{2}, \mathrm{PCCP} @ \mathrm{SiO}_{2}$ and pyrolytic PCCP@ $\mathrm{SiO}_{2}$, (d) Raman spectra for the samples of C-N,P,S and Pd/C-N,P,S. 
The cyclic voltammetry (CV) curves of Pd/C and Pd/C-N,P,S catalysts were measured in $1 \mathrm{~mol} / \mathrm{L}$ sodium hydroxide water solution. As shown in Figure $5 \mathrm{a}$, the hydrogen adsorption-desorption peak of $\mathrm{Pd} / \mathrm{C}-\mathrm{N}, \mathrm{P}, \mathrm{S}$ catalyst shows a higher current density between -1.0 and $-0.7 \mathrm{~V}$ vs. SCE. Besides, the peaks which is located at around $-0.35 \mathrm{~V}$ is the reduction peak of $\mathrm{PdO}_{\mathrm{x}}$. It is noting that there is a negative shift of $\sim 2 \mathrm{mV}$ for the Pd/C-N,P,S catalyst in comparison with $\mathrm{Pd} / \mathrm{C}$, indicating that the decreased oxophilicity on the Pd surfaces can reduce chemisorptions of these oxygen species, which benefits the EOR in the alkaline condition. Furthermore, the CV curves of $\mathrm{Pd} / \mathrm{C}-\mathrm{N}, \mathrm{P}, \mathrm{S}$ and $\mathrm{Pd} / \mathrm{C}$ in the sodium hydroxide and ethanol mixture solution were shown in Figure $5 \mathrm{~b}$. Obviously, the mass peak current density for $\mathrm{Pd} / \mathrm{C}-\mathrm{N}, \mathrm{P}, \mathrm{S}$ catalyst can reach $\sim 1686 \mathrm{~mA} \mathrm{mg}^{-1}$, which is 2.8 times higher than that of $\mathrm{Pd} / \mathrm{C}$. Also, the mass peak current density of $\mathrm{Pd} / \mathrm{C}-\mathrm{N}, \mathrm{P}, \mathrm{S}$ catalyst is higher than previously reported Pd-based EOR catalysts (Table S1), such as $\mathrm{Pd}-\mathrm{Ag}$ nanoparticles, $\mathrm{Pd}_{7} / \mathrm{Ru}_{1}$, etc. [36-42]. Considering the structure of the $\mathrm{Pd} / \mathrm{C}-\mathrm{N}, \mathrm{P}, \mathrm{S}$ catalyst, the doped N, P, and S atoms can significantly tune the electronic structure of the carbon shell of $\mathrm{C}-\mathrm{N}, \mathrm{P}, \mathrm{S}$. On the one hand, the $\mathrm{C}-\mathrm{N}, \mathrm{P}, \mathrm{S}$ with large surface area are conductive to the diffusion of electrolyte and charge transportation; on the other hand, the electrons can transfer from $\mathrm{Pd}$ to $\mathrm{C}-\mathrm{N}, \mathrm{P}, \mathrm{S}$ due to the existences of heteroatoms. The synergic effects between $\mathrm{Pd}$ and $\mathrm{C}-\mathrm{N}, \mathrm{P}, \mathrm{S}$ contributed the high electrochemical activity. More importanly, the $\mathrm{C}-\mathrm{N}, \mathrm{P}, \mathrm{S}$ supports also can faciliate the $\mathrm{CO}_{a d}$ intermediates.
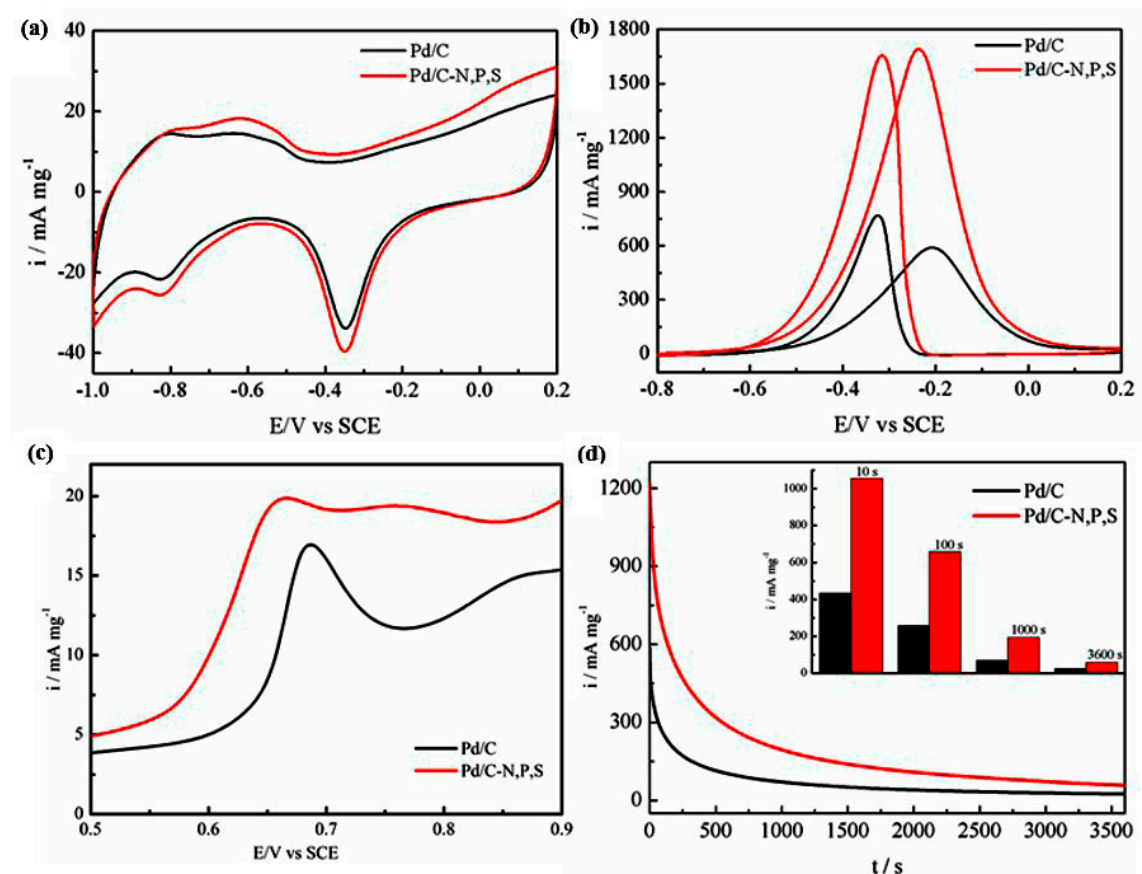

Figure 5. (a) Cyclic voltammetry (CV) of $\mathrm{Pd} / \mathrm{C}$ and $\mathrm{Pd} / \mathrm{C}-\mathrm{N}, \mathrm{P}, \mathrm{S}$ catalysts in sodium hydroxide (1 $\mathrm{mol} / \mathrm{L}),(\mathbf{b}) \mathrm{CVs}$ of $\mathrm{Pd} / \mathrm{C}$ and Pd/C-N,P,S catalysts in sodium hydroxide (1 mol/L) and ethanol (1 $\mathrm{mol} / \mathrm{L}$ ) mixture solution, (c) CO monolayer stripping voltammograms of the $\mathrm{Pd} / \mathrm{C}$ and $\mathrm{Pd} / \mathrm{C}-\mathrm{N}, \mathrm{P}, \mathrm{S}$ catalysts in diluted sulfuric acid solution $(0.5 \mathrm{~mol} / \mathrm{L}),(\mathrm{d})$ chronoamperometric curves for the the $\mathrm{Pd} / \mathrm{C}$ and $\mathrm{Pd} / \mathrm{C}-\mathrm{N}, \mathrm{P}, \mathrm{S}$ catalysts in sodium hydroxide $(1 \mathrm{~mol} / \mathrm{L})$ and ethanol $(1 \mathrm{~mol} / \mathrm{L})$ mixture solution at $-0.20 \mathrm{~V}$. Scan rate: $50 \mathrm{mV} / \mathrm{s}$.

The CO monolayer stripping curves of the $\mathrm{Pd} / \mathrm{C}$ and $\mathrm{Pd} / \mathrm{C}-\mathrm{N}, \mathrm{P}, \mathrm{S}$ catalysts were recorded in $0.5 \mathrm{~mol} / \mathrm{L}$ of sulfuric acid. As shown in Figure $5 \mathrm{c}$, the onset potential of $\mathrm{CO}$ oxidation on $\mathrm{Pd} / \mathrm{C}-\mathrm{N}, \mathrm{P}, \mathrm{S}$ catalyst is $0.665 \mathrm{~V}$. In comparison with $\mathrm{Pd} / \mathrm{C}$, there is a negative shift of $2.1 \mathrm{mV}$, indicating the $\mathrm{CO}_{a d s}$ can be oxidized at a lower potential on $\mathrm{Pd} / \mathrm{C}-\mathrm{N}, \mathrm{P}, \mathrm{S}$ catalyst. From CO-stripping $\mathrm{CV}$, the electrochemical surface areas (ECSA) can be calculated by CO desorption [43]. Considering the $420 \mu \mathrm{C} \mathrm{cm}^{-2}$ is the charge required to oxidize a monolayer of $\mathrm{CO}_{a d s}$ on Pd surface [44]. Therefore, the ECSA of the $\mathrm{Pd} / \mathrm{C}-\mathrm{N}, \mathrm{P}, \mathrm{S}$ catalyst is $76.31 \mathrm{~m}^{2} \mathrm{~g}^{-1}$, which was 2.76 times higher than that of the $\mathrm{Pd} / \mathrm{C}$. This indicated 
that the synergistic effects between the ternary doped hollow carbon sphere and those uniformly dispersed Pd particles which ensure the Pd/C-N,P,S catalyst with large ECSA and better anti-CO poisoning ability. Generally, the stability of an electrocatalyst is a very important factor for further practical application. The chronoamperometric measurement was carried out in the sodium hydroxide and ethanol mixture solution at a constant potential of $-0.2 \mathrm{~V}$. As shown in Figure $5 \mathrm{c}$, the Pd/C-N,P,S catalyst always exhibits the higher oxidation current density than that of the $\mathrm{Pd} / \mathrm{C}$ after different periods. After a repetitive 200 potential cycling tests, the peak current density of $\mathrm{Pd} / \mathrm{C}-\mathrm{N}, \mathrm{P}, \mathrm{S}$ has decreased by $\sim 4.2 \%$, and the peak current density of $\mathrm{Pd} / \mathrm{C}$ has decreased by $\sim 18.6 \%$. Obviously, the $\mathrm{Pd} / \mathrm{C}-\mathrm{N}, \mathrm{P}, \mathrm{S}$ shows higher structural stability than that of Pd/C. From Figure $5 \mathrm{~d}$, towards the ratio $\left(i_{3600} / i_{10}\right)$ of the peak current density after $3600 \mathrm{~s}$ to that after $10 \mathrm{~s}$, the $i_{3600} / i_{10}$ of $\mathrm{Pd} / \mathrm{C}-\mathrm{N}, \mathrm{P}, \mathrm{S}$ is $8.6 \%$ higher than that of $\mathrm{Pd} / \mathrm{C}(6.7 \%)$.

\section{Materials and Methods}

\subsection{Materials}

Tetraethoxysilane (TEOS), hexachlorocyclotriphos (HCCP), 4,4-sulfonyldiphenol (BPS), triethylamine (TEA), ethylenediaminetetraacetic acid (EDTA), acetonitrile, sodium carbonate, potassium tetrachloropalladate (II) $(99.95 \%)$, sodium tetrachloropalladate $(99.95 \%)$ were all obtained from Shanghai Aladdin Bio-Chem Technology Co.,Ltd (Shanghai, China). Ammonia water and ethanol were purchased from the Sinopharm Chemical Reagent Co. Ltd. (Shanghai, China). All chemicals and solvents were of analytical grade and used without further purification.

\subsection{Synthesis of $C-N, P, S$}

Figure 6 shows the schematic illustration of fabrication for $\mathrm{C}-\mathrm{N}, \mathrm{P}, \mathrm{S}$ hollow microsphere. Uniform $\mathrm{SiO}_{2}$ microsphere templates were fabricated by a reported method [45]. First, $0.2 \mathrm{~g}$ of $\mathrm{SiO}_{2}$ was dispersed into $200 \mathrm{~mL}$ of acetonitrile. Then, a certain amount of HCCP, BPS and TEA were added to the above $\mathrm{SiO}_{2}$ /acetonitrile dispersion with continuous stirring. After $6 \mathrm{~h}$ of stirring, the products of PCCP@SiO 2 was separated by centrifuge washing with water and ethanol, and then vacuum dried at $50{ }^{\circ} \mathrm{C}$ for $12 \mathrm{~h}$. Then, $\mathrm{PCCP} @ \mathrm{SiO}_{2}$ was subjected to pyrolysis under a nitrogen atmosphere. The pyrolysis condition is $600^{\circ} \mathrm{C}$ for $1 \mathrm{~h}$, and then $900{ }^{\circ} \mathrm{C}$ for $3 \mathrm{~h}\left(2{ }^{\circ} \mathrm{C} / \mathrm{min}\right)$. After being pyrolyzed, the $\mathrm{C}-\mathrm{N}, \mathrm{P}, \mathrm{S} @ \mathrm{SiO}_{2}$ was collected. IThen, the above $\mathrm{C}-\mathrm{N}, \mathrm{P}, \mathrm{S} @ \mathrm{SiO}_{2}$ was etched in $\mathrm{HF}$ to remove $\mathrm{SiO}_{2}$ microsphere templates. Finally, the $\mathrm{C}-\mathrm{N}, \mathrm{P}, \mathrm{S}$ was then washed by lots of water and vacuum dried overnight at $50^{\circ} \mathrm{C}$.

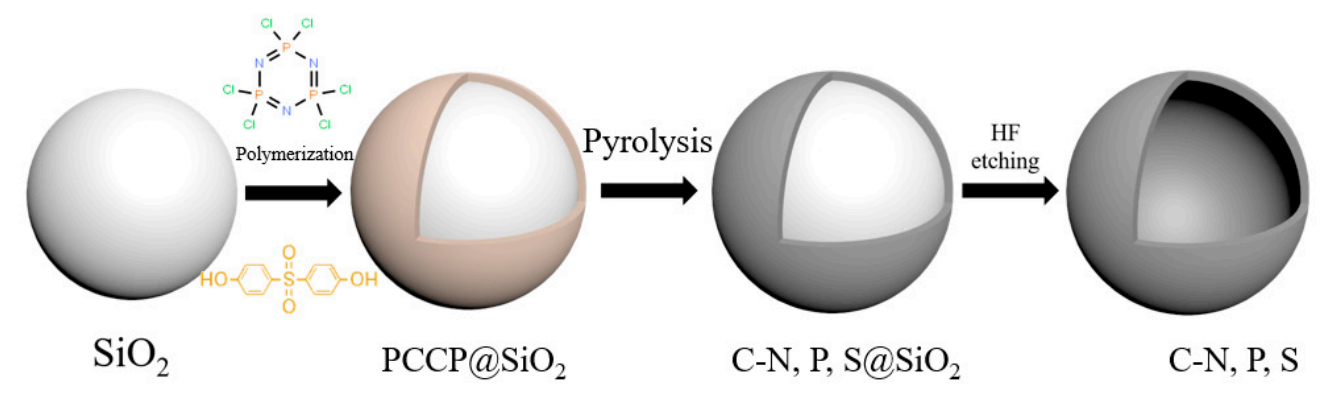

Figure 6. Schematic illustration for fabrication of hollow $\mathrm{C}-\mathrm{N}, \mathrm{P}, \mathrm{S}$ sphere.

\subsection{Preparation of $P d / C-N, P, S$ Catalysts}

The Pd/C-N,P,S was prepared by a simple and efficient chemical reduction impregnation method. $50 \mathrm{mg}$ of $\mathrm{C}-\mathrm{N}, \mathrm{P}, \mathrm{S}$ was first dispersed into $30 \mathrm{~mL}$ of $\mathrm{H}_{2} \mathrm{O}$ with bath sonication of $30 \mathrm{~min}$. Then, $50 \mathrm{mg}$ of $\mathrm{K}_{2} \mathrm{PdCl}_{4}$ and $50 \mathrm{mg}$ of EDTA were added into a C-N,P,S/water dispersion with continuous stirring. In the next stage, the $\mathrm{pH}$ value of above mixture solution was adjusted to about 10 by concentrated ammonia water. After that, $0.1 \mathrm{~g}$ of $\mathrm{Na}_{2} \mathrm{CO}_{3}$ and $0.1 \mathrm{~g}$ of $\mathrm{NaBH}_{4}$ were dissolved in $20 \mathrm{~mL}$ of $\mathrm{H}_{2} \mathrm{O}$ as 
reductant solution. The reductant solution was slowly added dropwise to the previous dispersion. After reaction of $4 \mathrm{~h}$ with stirring, the $\mathrm{Pd} / \mathrm{C}-\mathrm{N}, \mathrm{P}, \mathrm{S}$ was collected by centrifugation. After washing by water and ethanol, the Pd/C-N,P,S was vacuum dried at $70{ }^{\circ} \mathrm{C}$ for $12 \mathrm{~h}$.

\subsection{Electrocatalytic Activity Test}

A CHI 660E electrochemistry workstation (Shanghai, China) was used for testing the electrocatalytic performance of all catalysts with a conventional three-electrode method. The graphite rod electrode was employed as counter electrode. A saturated calomel electrode (SCE) was the reference electrode. The Pd/C-N,P,S and Pd/C modified glassy carbon electrodes $(\Phi=3 \mathrm{~mm})$ were used as the working electrodes. $\mathrm{CO}$ stripping experiment was peformed in diluted sulfuric acid solution. CV tests and chronoamperometry were undertaken in the sodium hydroxide and ethanol mixture solution.

\subsection{Catalysts Characterization}

X-ray diffraction (XRD) patterns were obtained from a Bruker D8 Advance X-ray diffractometer (Karlsruhe, Germany). The morphology and microstructure of all catalysts were characterized by field-emission scanning electron microscopy (FE-SEM, JSM-7800F, Tokyo, Japan) and transmission electron microscopy (TEM, JEOL JEM-2100F electron microscope, Tokyo, Japan). XPS measurements were performed on a Kratos Axis Ultra DLD (Kratos Analytical, Manchester, UK) with an Al K $\alpha$ X-ray $(1486.6 \mathrm{eV})$. Fourier transform-infrared spectroscopy (FT-IR) analyses were obtained with a FTIR-8400S spectrometer (Kratos Analytical, Manchester, UK).

\section{Conclusions}

In summary, the Pd/C-N,P,S with Pd NPs decorated on the surfaces of ternary N, S, and P-doped hollow carbon microspheres was successfully prepared using the $\mathrm{SiO}_{2}$ microspheres and PCCP as templates and carbon source. As EOR catalyst, the $\mathrm{Pd} / \mathrm{C}-\mathrm{N}, \mathrm{P}, \mathrm{S}$ exhibits high electrochemical activity with a mass peak current density of $1686 \mathrm{~mA} \mathrm{mg}^{-1}$ which is 2.8 times higher than that of $\mathrm{Pd} / \mathrm{C}$. Remarkably, the ECSA of the Pd/C-N,P,S catalyst can reach $\sim 76.31 \mathrm{~m}^{2} \mathrm{~g}^{-1}$ which is 2.76 times higher that of the Pd/C. In addition, the Pd/C-N,P,S catalyst also shows good stability. The high performance of $\mathrm{Pd} / \mathrm{C}-\mathrm{N}, \mathrm{P}, \mathrm{S}$ catalysts may be mainly due to the following reasons: (1) the porous $\mathrm{C}-\mathrm{N}, \mathrm{P}, \mathrm{S}$ with large surface area are conductive to the diffusion of electrolyte and charge transportation, and (2) the electrons can transfer from $\mathrm{Pd}$ to $\mathrm{C}-\mathrm{N}, \mathrm{P}, \mathrm{S}$ due to the existences of heteroatoms. Also, the $\mathrm{C}-\mathrm{N}, \mathrm{P}, \mathrm{S}$ supports can also faciliate the $\mathrm{CO}_{a d}$ intermediates. The synergic effects between $\mathrm{Pd}$ and $\mathrm{C}-\mathrm{N}, \mathrm{P}, \mathrm{S}$ contributed to the high electrochemical activity. Therefore, the $\mathrm{Pd} / \mathrm{C}-\mathrm{N}, \mathrm{P}, \mathrm{S}$ catalyst has promising prospects for high-performance EOR catalysts.

Supplementary Materials: The following are available online at http:/ /www.mdpi.com/2073-4344/9/2/114/s1: Figure S1: CVs of Pd/C-N,P,S catalysts in sodium hydroxide $(1 \mathrm{~mol} / \mathrm{L})$ at different scan rates; Figure S2: The calibration plot of oxidation and reduction peaks currents vs. scan rate; Figure S3: CVs of Pd/C-N,P,S and $\mathrm{Pd} / \mathrm{C}$ after 200 repetitive potential cycling tests, Table S1: The mass peak current densities of various reported EOR catalysts.

Author Contributions: Conceptualization, J.F., Q.L., P.S., Q.X., Y.M.; methodology, J.F., Q.L., P.S., Q.X., Y.M.; software, J.F., Q.L., P.S., Q.X., Y.M.; validation, K.Y., Y.L., J.F., Q.L., P.S., Q.X., Y.M.; formal analysis, K.Y., Y.L.; investigation, K.Y., Y.L., J.F., Q.L., P.S., Q.X., Y.M.; resources, K.Y., Y.L., J.F., Q.L., P.S., Q.X., Y.M.; data curation, K.Y., Y.L., J.F., Q.L., P.S., Q.X., Y.M.; writing—original draft preparation, K.Y., Y.L., Q.X.; writing一review and editing, J.F., Q.L., P.S., Q.X., Y.M.; supervision, Q.L., P.S., Y.M., J.F.; project administration, J.F., Q.X., Y.M.; funding acquisition, J.F., Q.X., Y.M. All authors discussed the results and commented on the manuscript.

Funding: This research was funded by the National Natural Science Foundation of China (Nos.91745112, 21473039, and 21604051). This work was also supported by the Shanghai Municipal Education Commission (Nos. 15ZZ088 and 15SG49), and the Science and Technology Commission of Shanghai Municipality (18020500800).

Conflicts of Interest: The authors declare no conflict of interest. 


\section{References}

1. Antolini, E.; Gonzalez, E.R. Alkaline direct alcohol fuel cells. J. Power Sources 2010, 195, 3431-3450. [CrossRef]

2. Antolini, E. Palladium in fuel cell catalysis. Energy Environ. Sci. 2009, 2, 915-931. [CrossRef]

3. Bianchini, C.; Shen, P.K. Palladium-Based Electrocatalysts for Alcohol Oxidation in Half Cells and in Direct Alcohol Fuel Cells. Chem. Rev. 2009, 109, 4183-4206. [CrossRef] [PubMed]

4. Martins, C.A.; Fernandez, P.S.; Lima, F.D.; Troiani, H.E.; Martins, M.E.; Arenillas, A.; Maia, G.; Camara, G.A. Remarkable electrochemical stability of one-step synthesized Pd nanoparticles supported on grapheme and multi-walled carbon nanotubes. Nano Energy 2014, 9, 142-151. [CrossRef]

5. Dutta, A.; Ouyang, J.Y. Ternary NiAuPt nanoparticles on reduced graphene oxide as catalysts toward the electrochemical oxidation reaction of ethanol. ACS Catal. 2015, 5, 1371-1380. [CrossRef]

6. Zadick, A.; Dubau, L.; Sergent, N.; Berthome, G.; Chatenet, M. Huge instability of Pt/C catalysts in alkaline medium. ACS Catal. 2015, 5, 4819-4824. [CrossRef]

7. Sneed, B.T.; Young, A.P.; Jalalpoor, D.; Golden, M.C.; Mao, S.; Jiang, Y.; Wang, Y.; Tsung, C.K. Shaped Pd-Ni-Pt Core-Sandwich-Shell Nanoparticles: Influence of Ni Sandwich Layers on Catalytic Electrooxidation. ACS Nano 2014, 7, 7239-7250. [CrossRef]

8. Wang, E.D.; Xu, J.B.; Zhao, T.S. Density Functional Theory Studies of the Structure Sensitivity of Ethanol Oxidation on Palladium Surfaces. J. Phys. Chem. C 2010, 114, 10489-10497. [CrossRef]

9. Wang, Y.; Shi, F.; Yang, Y.; Cai, W. Carbon supported Pd-Ni-P nanoalloy as an efficient catalyst for ethanol electro-oxidation in alkaline media. J. Power Sources 2013, 243, 369-373. [CrossRef]

10. Ahmed, M.S.; Jeon, S.W. Highly Active Graphene-Supported NixPd100-x Binary Alloyed Catalysts for Electro-Oxidation of Ethanol in an Alkaline Media. ACS Catal. 2014, 4, 1830-1837. [CrossRef]

11. Wang, L.; Lavacchi, A.; Bevilacqua, M.; Bellini, M.; Fornasiero, P.; Filippi, J.; Innocenti, M.; Marchionni, A.; Miller, H.A.; Vizza, F. Energy efficiency of alkaline direct ethanol fuel cells employing nanostructured palladium electrocatalysts. Chem CatChem 2015, 7, 2214-2221. [CrossRef]

12. Singh, R.N.; Awasthi, R. Graphene support for enhanced electrocatalytic activity of Pd for alcohol oxidation. Catal. Sci. Technol. 2011, 1, 778-783. [CrossRef]

13. Lin, Y.; Liu, Q.; Fan, J.C.; Liao, K.X.; Xie, J.W.; Liu, P.; Chen, Y.H.; Min, Y.L.; Xu, Q.J. Highly dispersed palladium nanoparticles on poly $\left(\mathrm{N}_{1}, \mathrm{~N}_{3}\right.$-dimethylbenzimidazolium) iodide-functionalized multiwalled carbon nanotubes for ethanol oxidation in alkaline solution. RSC Adv. 2016, 6, 102582-102594. [CrossRef]

14. Chang, J.F.; Feng, L.G.; Liu, C.P.; Xing, W.; Hu, X.L. An effective Pd-Ni 2 P/C anode catalyst for direct formic acid fuel cells. Angew. Chem. Int. Ed. 2014, 53, 122-126. [CrossRef] [PubMed]

15. Chen, A.; Ostrom, C. Palladium-based nanomaterials: Synthesis and electrochemical applications. Chem. Rev. 2015, 115, 11999-12044. [CrossRef] [PubMed]

16. Yan, Z.; Meng, H.; Shi, L. Synthesis of mesoporous hollow carbon hemispheres as highly efficient Pd electrocatalyst support for ethanol oxidation. Electrochem. Commun. 2010, 12, 689-692. [CrossRef]

17. Iijima, S. Helical microtubules of graphitic carbon. Nature 1991, 354, 56-58. [CrossRef]

18. Zhang, Q.; Jiang, L.; Wang, H. Hollow graphitized carbon nanocage supported Pd catalyst with excellent electrocatalytic activity for ethanol oxidation. ACS Sustain. Chem. Eng. 2018, 6, 7507-7514. [CrossRef]

19. Kim, A.; Bae, H.S.; Park, J.C.; Song, H. Surfactant-free pd@ $\mathrm{pSiO}_{2}$ yolk-shell nanocatalyst for selective oxidation of primary alcohols to aldehydes. New J. Chem. 2015, 39, 8153-8157. [CrossRef]

20. Jinwoo, K.; Aram, K.; Nallal, M.; Kang, P. PdO/ZnO@mSiO 2 hybrid nanocatalyst for reduction of nitroarenes. Catalysts 2018, 8, 280.

21. Aram, K.; Nallal, M.; Chohye, Y.; Sang, J.; Kang, P. MOF-derived Cu@ $@ \mathrm{Cu}_{2} \mathrm{O}$ nanocatalyst for oxygen reduction reaction and cycloaddition reaction. Nanomaterials 2018, 8, 138.

22. Choi, C.H.; Park, S.H.; Woo, S.I. Binary and ternary doping of nitrogen, boron, and phosphorus into carbon for enhancing electrochemical oxygen reduction activity. ACS Nano 2012, 8, 7084-7091. [CrossRef] [PubMed]

23. Jiang, Z.; Jiang, Z.J.; Maiyalagan, T.; Manthiram, A. Cobalt oxide-coated N- and B-doped graphene hollow spheres as a bifunctional electrocatalyst for oxygen reduction and oxygen evolution reactions. J. Mater. Chem. A 2016, 4, 5877-5889. [CrossRef] 
24. Liu, M.; Song, Y.; He, S.; Tjiu, W.W.; Pan, J.; Xia, Y.; Liu, T. Nitrogen-doped graphene nanoribbons as efficient metal-free electrocatalysts for oxygen reduction. ACS Appl. Mater. Interfaces 2014, 6, 4214-4222. [CrossRef] [PubMed]

25. Cazetta, A.L.; Zhang, T.; Silva, T.L.; Almeida, V.C.; Asefa, T. Bone char-derived metal-free N- and S-co-doped nanoporous carbon and its efficient electrocatalytic activity for hydrazine oxidation. Appl. Catal. B 2018, 225, 30-39. [CrossRef]

26. Choi, C.H.; Chung, M.W.; Park, S.H.; Woo, S.I. Additional doping of phosphorus and or sulfur into nitrogen-doped carbon for efficient oxygen reduction reaction in acidic media. Phys. Chem. Chem. Phys. 2013, 15, 1802-1805. [CrossRef] [PubMed]

27. Liu, Q.; Fan, J.C.; Min, Y.L.; Wu, T.; Lin, Y.; Xu, Q.J. B, N-codoped graphene nanoribbons supported Pd nanoparticles for ethanol electrooxidation enhancement. J. Mater. Chem. A 2016, 4, 4929-4933. [CrossRef]

28. Sanchez, M.L.; Primo, A.; Garcia, H. P-doped graphene obtained by pyrolysis of modified alginate as a photocatalyst for hydrogen generation from water-methanol mixtures. Angew. Chem. 2013, 52, 11813-11816. [CrossRef] [PubMed]

29. Choi, C.H.; Chung, M.W.; Kwon, H.C.; Park, S.H.; Woo, S.I. N- and P, N-doped graphene as highly active catalysts for oxygen reduction reactions in acidic media. J. Mater. Chem. A 2013, 1, 3694-3699. [CrossRef]

30. Wei, W.; Wang, Q.; Zhang, L.; Liang, H.W.; Chen, P.; Yu, S.H. N-, P- and Fe-tridoped nanoporous carbon derived from plant biomass: An excellent oxygen reduction electrocatalyst for zinc-air battery. J. Mater. Chem. A 2016, 4, 8602-8609.

31. Zhang, G.G.; Zang, S.H.; Wang, X.C. Layered $\mathrm{Co}(\mathrm{OH})_{2}$ deposited polymeric carbon nitrides for photocatalytic water oxidation. ACS Catal. 2015, 5, 941-947. [CrossRef]

32. Zhang, C.Z.; Nasir, M.; Yin, H.; Liu, F.; Hou, Y.L. Synthesis of phosphorus-doped graphene and its multifunctional applications for oxygen reduction reaction and lithium ion batteries. Adv. Mater. 2013, 25, 4932-4937. [CrossRef] [PubMed]

33. Yang, G.; Chen, Y.; Zhou, Y.; Tang, Y.; Lu, T. Preparation of carbon supported Pd-P catalyst with high content of element phosphorus and its electrocatalytic performance for formic acid oxidation. Electrochem. Commun. 2010, 12, 492-495. [CrossRef]

34. Zhang, X.; Zhu, J.X.; Chandra, S.T.; Ma, Z.Y.; Huang, H.J.; Zhang, J.F.; Lu, Z.Y.; Huang, W.; Wu, Y.P. Palladium nanoparticles supported on nitrogen and sulfur dual-doped graphene as highly active electrocatalysts for formic acid and methanol oxidation. ACS Appl. Mater. Interfaces 2016, 8, 10858-10865. [CrossRef] [PubMed]

35. Fu, J.W.; Xu, Q.; Chen, J.F.; Chen, Z.M.; Huang, X.B.; Tang, X.Z. Controlled fabrication of uniform hollow core porous shell carbon spheres by the pyrolysis of core/shell polystyrene/cross-linked polyphosphazene composites. Chem. Commun. 2010, 46, 6563-6565. [CrossRef] [PubMed]

36. Hong, J.W.; Kim, Y.; Wi, D.H.; Lee, S.; Lee, S.-U.; Lee, Y.W.; Choi, S.-I.; Han, S.W. Ultrathin Free-Standing Ternary-Alloy Nanosheets. Angew. Chem. Int. Ed. 2016, 55, 2753-2758. [CrossRef] [PubMed]

37. Shi, Q.; Zhang, P.; Li, Y.; Xia, H.; Wang, D.; Tao, X. Synthesis of open-mouthed, yolk-shell Au@AgPd nanoparticles with access to interior surfaces for enhanced electrocatalysis. Chem. Sci. 2015, 6, 4350-4357. [CrossRef]

38. Ye, S.-H.; Feng, J.-X.; Li, G.-R. Pd Nanoparticle/CoP Nanosheet Hybrids: Highly Electroactive and Durable Catalysts for Ethanol Electrooxidation. ACS Catal. 2016, 6, 7962-7969. [CrossRef]

39. Zhang, K.; Bin, D.; Yang, B.; Wang, C.; Ren, F.; Du, Y. Ru-assisted synthesis of Pd/Ru nanodendrites with high activity for ethanol electrooxidation. Nanoscale 2015, 7, 12445-12451. [CrossRef]

40. Wang, A.-L.; He, X.-J.; Lu, X.-F.; Xu, H.; Tong, Y.-X.; Li, G.-R. Palladium-Cobalt Nanotube Arrays Supported on Carbon Fiber Cloth as High-Performance Flexible Electrocatalysts for Ethanol Oxidation. Angew. Chem. Int. Ed. 2015, 54, 3669-3673. [CrossRef]

41. Chen, H.; Huang, Y.; Tang, D.; Zhang, T.; Wang, Y. Ethanol oxidation on Pd/C promoted with $\mathrm{CaSiO}_{3}$ in alkaline medium. Electrochim. Acta 2015, 158, 18-23. [CrossRef]

42. Li, L.; Chen, M.; Huang, G.; Yang, N.; Zhang, L.; Wang, H.; Liu, Y.; Wang, W.; Gao, J. A green method to prepare Pd-Ag nanoparticles supported on reduced graphene oxide and their electrochemical catalysis of methanol and ethanol oxidation. J. Power Sources 2014, 263, 13-21. [CrossRef]

43. Spendelow, J.S.; Lu, G.Q.; Kenis, P.J.A.; Wieckowski, A. Electrooxidation of adsorbed CO on Pt(111) and $\mathrm{Pt}(111) / \mathrm{Ru}$ in alkaline media and comparison with results from acidic media. J. Electroanal. Chem. 2004, 568, 215-224. [CrossRef] 
44. Zhao, Y.; Yang, X.; Tian, J.; Wang, F.; Zhan, L. A facile and novel approach toward synthetic polypyrrole oligomers functionalization of multi-walled carbon nanotubes as PtRu catalyst support for methanol electro-oxidation. J. Power Sources 2010, 195, 4634-4640. [CrossRef]

45. Stöber, W.; Fink, A.; Bohn, E. Controlled growth of monodisperse silica spheres in the micron size range. J. Colloid Interface Sci. 1968, 26, 62-69. [CrossRef] 